\title{
Utilization of Wavewatch III Model Output Data for High Wave Analysis
}

\author{
Ricky Daniel Aror ${ }^{1,2 *}$, Wilhelmina Patty ${ }^{2}$, Andri Ramdhani ${ }^{3}$ \\ ${ }^{1}$ Bitung Marine Meteorological Station \\ Jl. Candi No.53 Kadoodan, Madidir, Kota Bitung 95513 Indonesia \\ ${ }^{2}$ Aquatic Science, Faculty of Fishery and Marine Science, Sam Ratulangi University \\ Jl. Kampus Bahu, Manado 95115 Indonesia \\ ${ }_{3}^{3}$ Maritime Meteorology Center, Meteorology Climatology and Geophysics Agency \\ Jl. Angkasa 1 No.2, Jakarta Pusat 10720 Indonesia \\ Email: ricky.aror@bmkg.go.id
}

\begin{abstract}
This study discusses the occurrence of extreme waves in North Sulawesi waters from 17 to 24 June 2016 using Wavewatch III (WW3) model output data with resolution $0.125^{\circ} \times 0.125^{\circ}$ extracted from MIDAS-BMKG. The extracted WW3 data is mapped using ArcMap and presented in graphical form. Based on the results of the study, the significant wave height is in the range of 0.0 to $1.0 \mathrm{~m}$ and the average wind speed ranges from 0 to $15 \mathrm{knots}$ in the early phase of 17-19 June 2016. Significant wave increases in the peak phase of 20-22 June 2016 that reaches 1.5-2.0 $\mathrm{m}$ and average wind speeds reach 25 knots. The average wind speed and the significant wave height decreased after June 23, 2016. The high of the significant wave are influenced by the low-pressure circulation in the atmosphere near the Sangihe-Talaud Islands. Further study can be done as a comparison of this study e.g. using wave data from altimeter satellites or comparing with other parameters such as the influence of swell and wind sea.
\end{abstract}

Keywords: Significant wave height, wind, Wavewatch III (WW3)

\section{Introduction}

Indonesia is an archipelagic country that stretch from Sabang to Merauke (Karsidi, 2014). As an archipelagic country, marine transportation becomes an important vehicle for the mobility of passengers and goods inter island, including North Sulawesi waters. Sea transportation becomes a solution that can transport passengers and more goods than using air transportation (Rildo et al., 2016). The waters around North Sulawesi have long been used as a shipping and trade route (Kaunang et al., 1999).

One of the aspects which determine the smoothness of sea and air transportation is weather condition (Oktaviani, 2014). High wave information of sea, wind and other weather parameters is needed by ships that will make the voyage (Rustendi, 2015). High winds and high waves can increase the risk of shipwrecking crashes, especially on relatively small ships (Suwardjo, et al., 2010).

The problem studied in this study is what kind of sea wave conditions that could cause natural disasters in the Sangihe Islands in mid-June 2016 and how the mapping results use Wavewatch III output data. This study aims to test the data extraction model Wavewatch III in understanding the conditions of winds and waves during extreme weather that could cause natural disasters in this region.

Wavewatch III (WW3) is a 3rd generation marine wave model developed by Marine Modeling and Analysis Branch (MMAB) at the Environmental Modeling Center (EMC) at the National Centers for Environmental Prediction (NCEP) (Tolman, 2014). WW3 produces a significant wave height that has good conformance with buoy observation data and altimetry satellite data (Ramdhani, 2015). WW3 can be used to simulate waves in deep waters and in shallow waters (Ortiz-Royero and Mercado-Irizarry, 2008). The wave studies using WW3 should pay attention to some inputs such as wind and bathymetry in order to produce a better calculation (Eshleman et al., 2007; Zijlema, 2010; Sofian, 2012). Output data of WW3 will be used in this research to analyze high wave incidence in Sangihe Islands Waters.

\section{Materials and Methods}

The research area is in position $118^{\circ} \mathrm{E}-128^{\circ} \mathrm{E}$ and $7^{\circ} \mathrm{N}-1^{\circ} \mathrm{S}$ which includes the Sulawesi Sea, 
Sangihe-Talaud Waters and the Maluku Sea (Figure $1)$. The sample point is taken at eight points on the coordinates $A 1\left(220^{\circ} \mathrm{E}, 4^{\circ} \mathrm{N}\right), \mathrm{B} 1\left(22^{\circ} \mathrm{E}, 4^{\circ} \mathrm{N}\right), \mathrm{C} 1$ $\left(224^{\circ} \mathrm{E}, 4^{\circ} \mathrm{N}\right)$, D1 $\left(226^{\circ} \mathrm{E}, 4^{\circ} \mathrm{N}\right)$, A2 $\left(20^{\circ} \mathrm{E}, 2^{\circ} \mathrm{N}\right)$, B2 $\left(222^{\circ} \mathrm{E}, 2^{\circ} \mathrm{N}\right), \mathrm{C}^{2}\left(24^{\circ} \mathrm{E}, 2^{\circ} \mathrm{N}\right)$ and $\mathrm{D} 2\left(226^{\circ} \mathrm{E}, 2^{\circ} \mathrm{N}\right)$. Software that is used for data processing was ArcMap 10.3.

WW3 model output data sourced from the Meteorology Climatology and Geophysics Agency of Indonesia (BMKG, 2016) which is a hindcast data of wind and wave height with a resolution of $0,125^{\circ} x$ $0,125^{\circ}$. The WW3 data is then extracted and stored into a readable format as data having dimensions $x, y$ and $z$ (longitude, latitude and wave height). Then the data is sorted to take eight sample points at the specified coordinates. The data are then displayed in the form of two graphs each representing latitude $4^{\circ} \mathrm{N}$ (line 1) and latitude $2^{\circ} \mathrm{N}$ (line 2) and explained descriptively.

Mapping is processed spatially using ArcMap 10.3. Significant wave heights are mapped in color gradations at intervals of $0,0.5,0.75,1,1.25,1.5,2$, $2.5,3,3.5,4,5,6,7$ in meters $(\mathrm{m})$. Wind speed is mapped with intervals of $0,2,4,6,8,10,15,20,25$, $30,35,40,50,60$ in knots. The determination of the color gradient and the interval follows the wind and wave mapping issued by BMKG (BMKG, 2017). The mapping results are analyzed by looking at the relationship between wind speed and significant wave in the three phases of the initial phase of 17-19 June 2016, the peak phase of 20-22 June 2017 and the final phase of the date of 23 to 24 June 2016.

\section{Results and Discussion}

Based on reports from several sources, extreme weather that caused high waves in the region of Sangihe Archipelago, North Sulawesi occurred on Tuesday, June 21, 2016 (Hidayat and Hari, 2016; Srisurya, 2016; BBC Indonesia, 2016). The analysis of air pressure released by the Bureau of Meteorology (BOM) shows the presence of low pressure areas in the northeast of the SangiheTalaud Islands at coordinates of $129^{\circ} \mathrm{E}$ and $06^{\circ} \mathrm{N}$ at that date. (Figure 2.). Circulation systems of low pressure areas can trigger extreme weather. (Assyakur, 2007)

In general, the average wind velocity in North Sulawesi waters in the early phase (17-19 June 2016 ) is in the range $0-15$ knots and the significant wave height is in the range $0-1.0 \mathrm{~m}$ (Figure 3.). At peak phase (20-22 June 2016) the average wind speed reached 25 knots in the waters of the SangiheTalaud Islands (Figure 4c.) and significant wave heights reached $2.0 \mathrm{~m}$ (Figure 4d.). Average wind speed and wave height decreased in the final phase (23 - 24 June 2016) (Figure 5.).

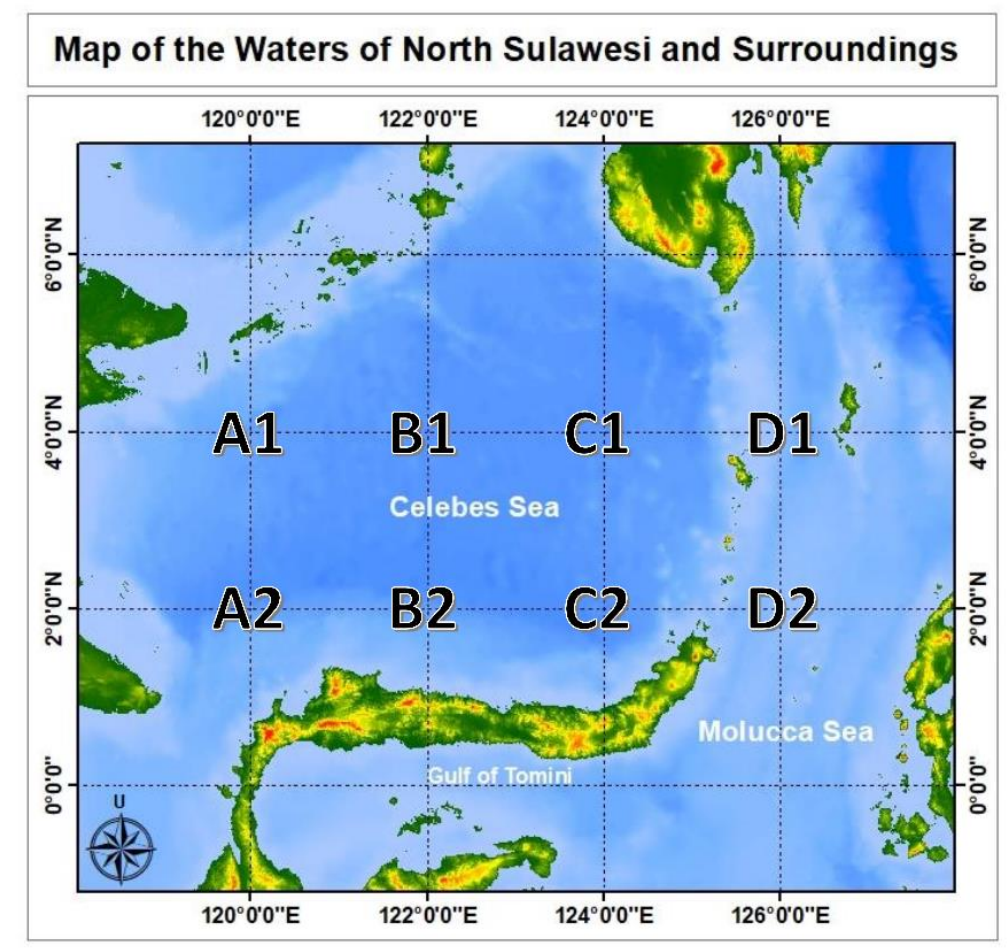

Figure 1. Map of the Water of North Sulawesi and Surroundings 

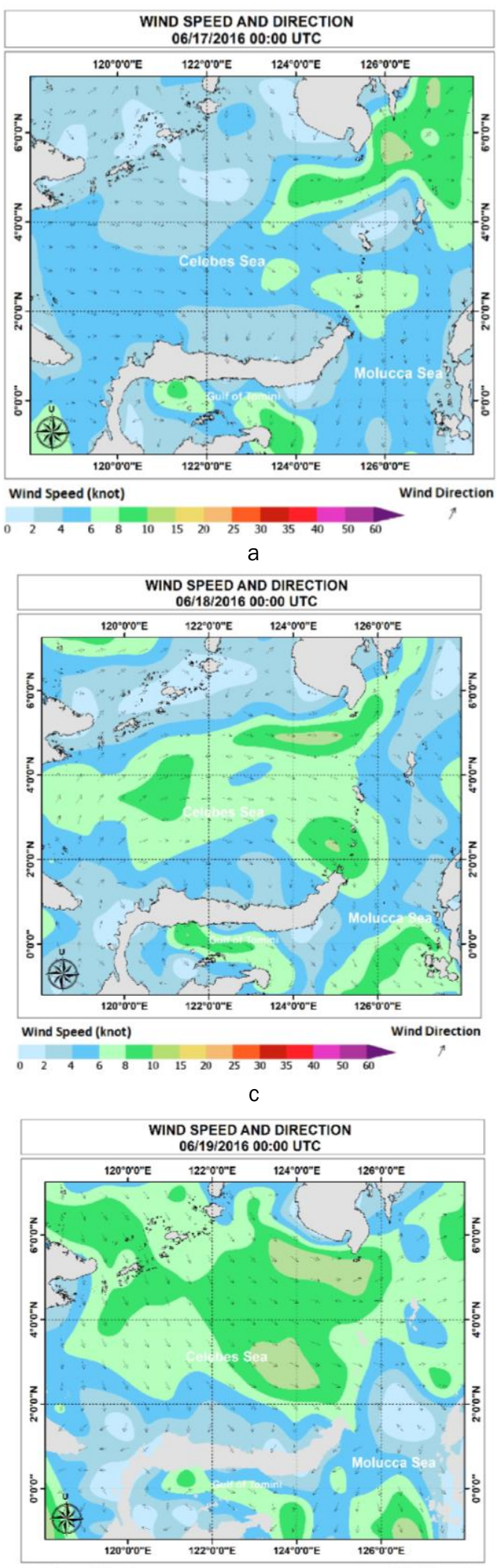

Wind Speed (knot) Wind Direction $\begin{array}{lllllllllllllll}0 & 2 & 4 & 6 & 8 & 10 & 15 & 20 & 25 & 30 & 35 & 40 & 50 & 60 & \pi\end{array}$

e
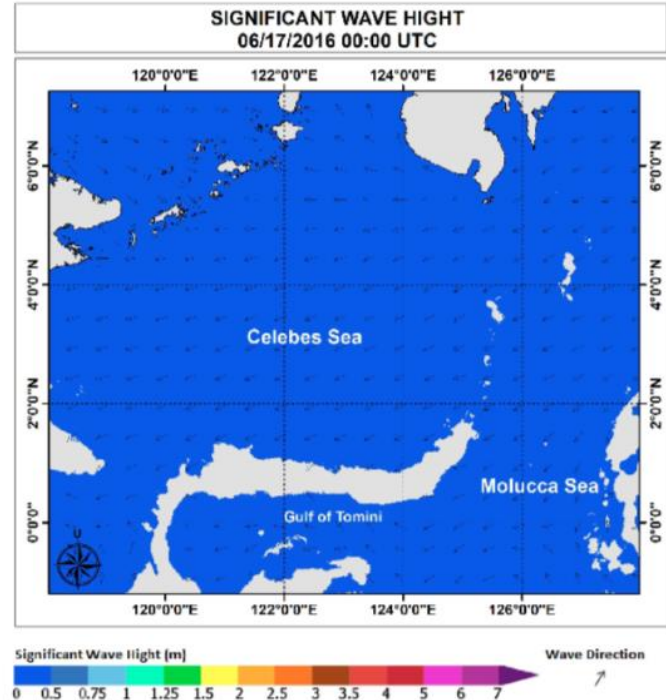

b
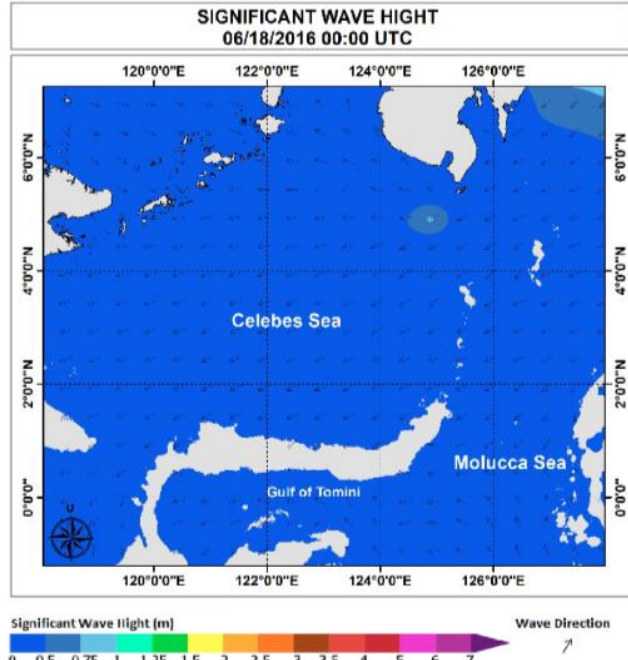

d
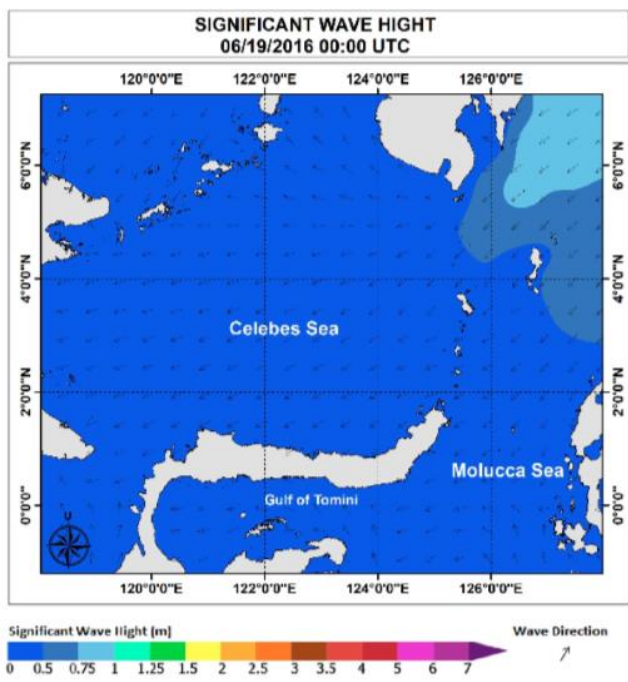

$\bar{f}$

Figure 3. Analysis map of wind and significant wave in the initial phase (17-19 June 2016) 

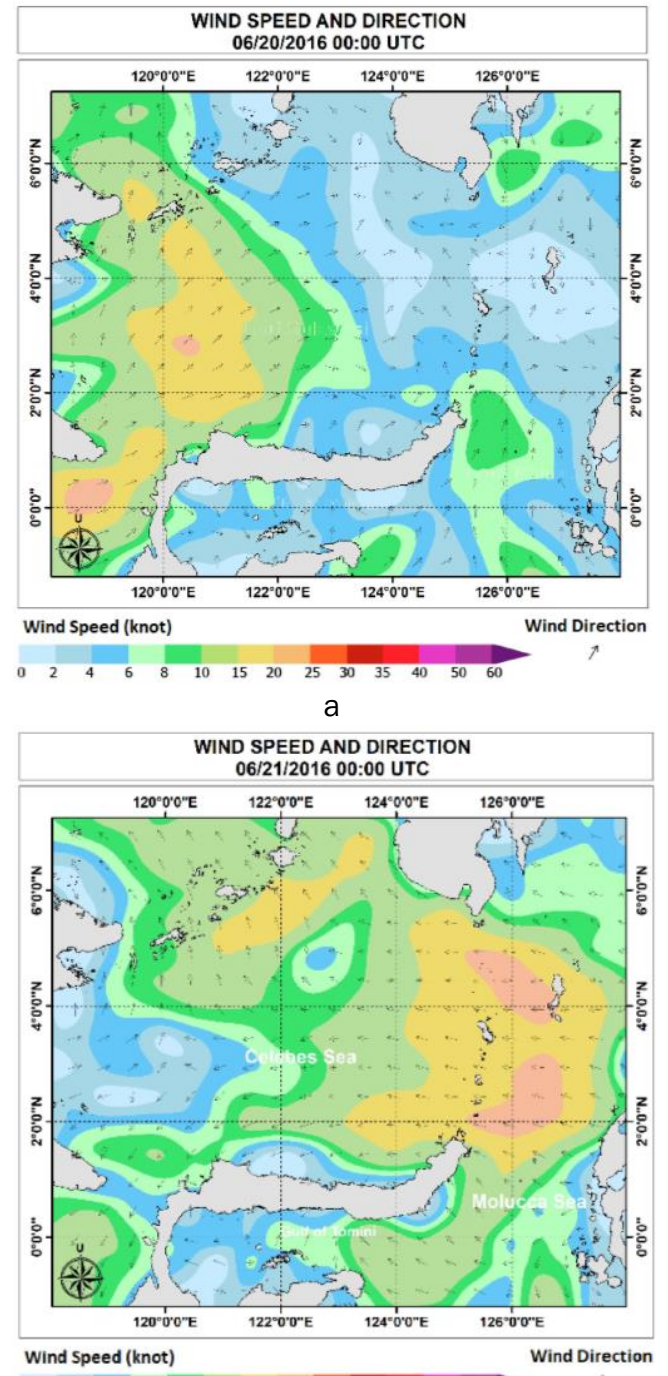

$\begin{array}{lllllllllllllll}0 & 2 & 4 & 6 & 8 & 10 & 15 & 20 & 25 & 30 & 35 & 40 & 50 & 60\end{array}$

C

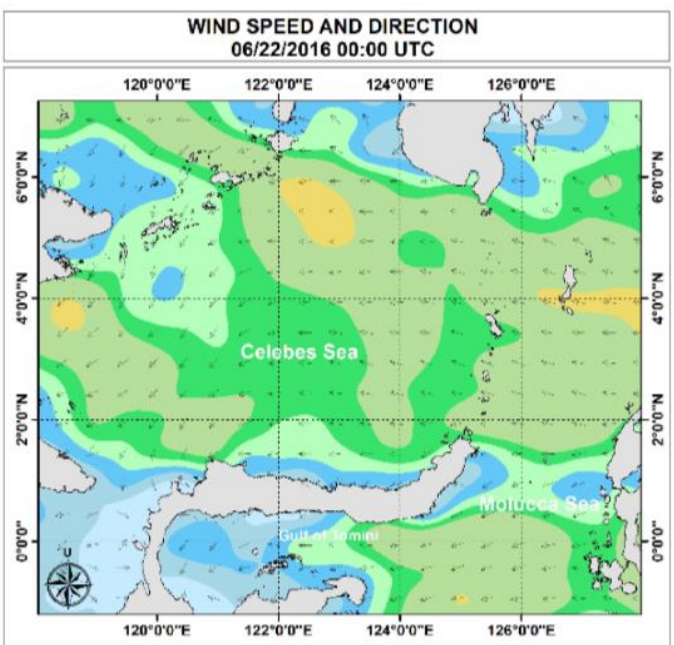

Wind Speed (knot)

$\begin{array}{lllllllllllllll}0 & 2 & 4 & 6 & 8 & 10 & 15 & 20 & 25 & 30 & 35 & 40 & 50 & 60\end{array}$
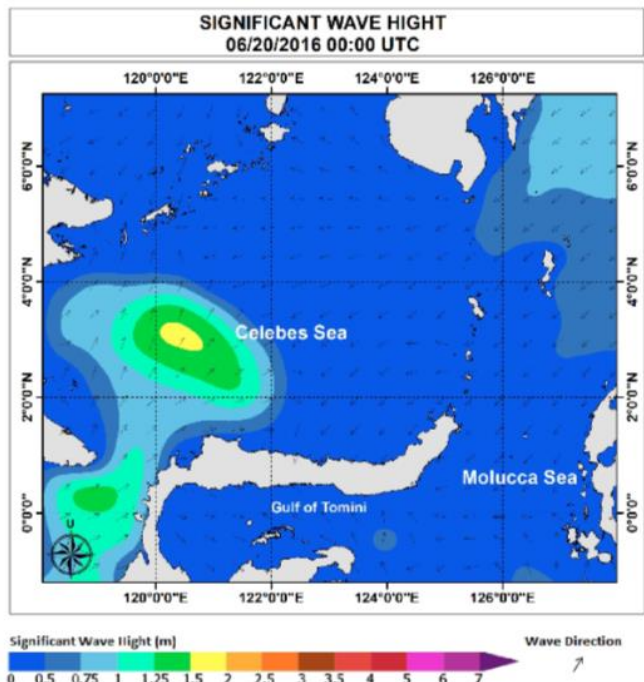

b
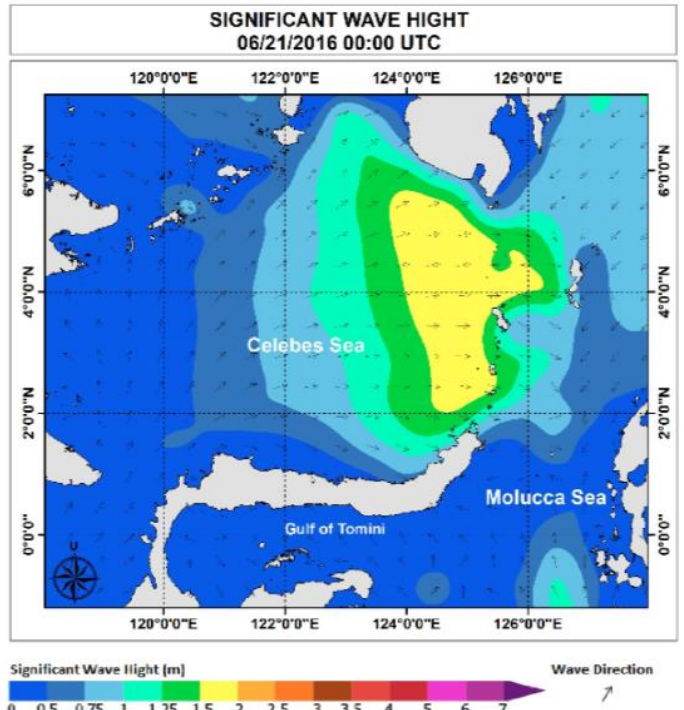

d
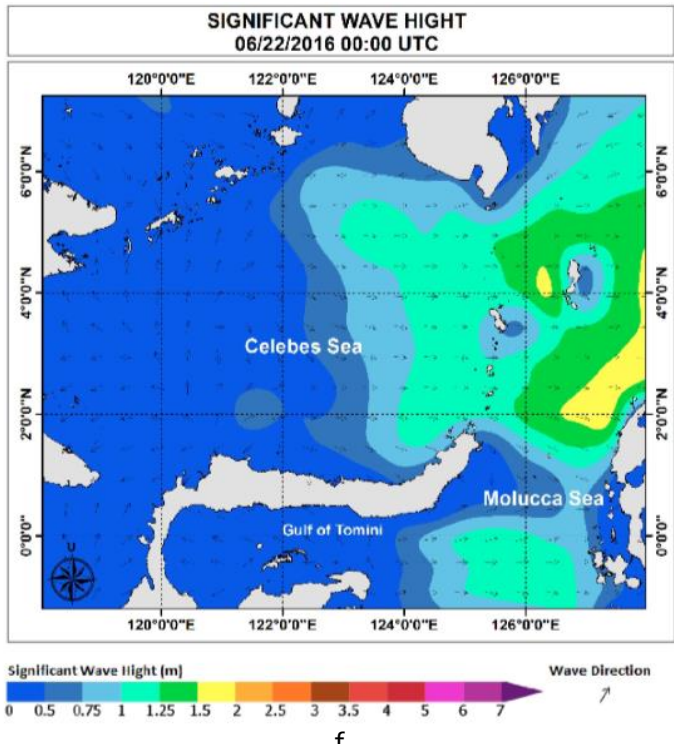

f

Figure 4. Analysis map of wind and significant wave in the peak phase (20 - 22 June 2016) 

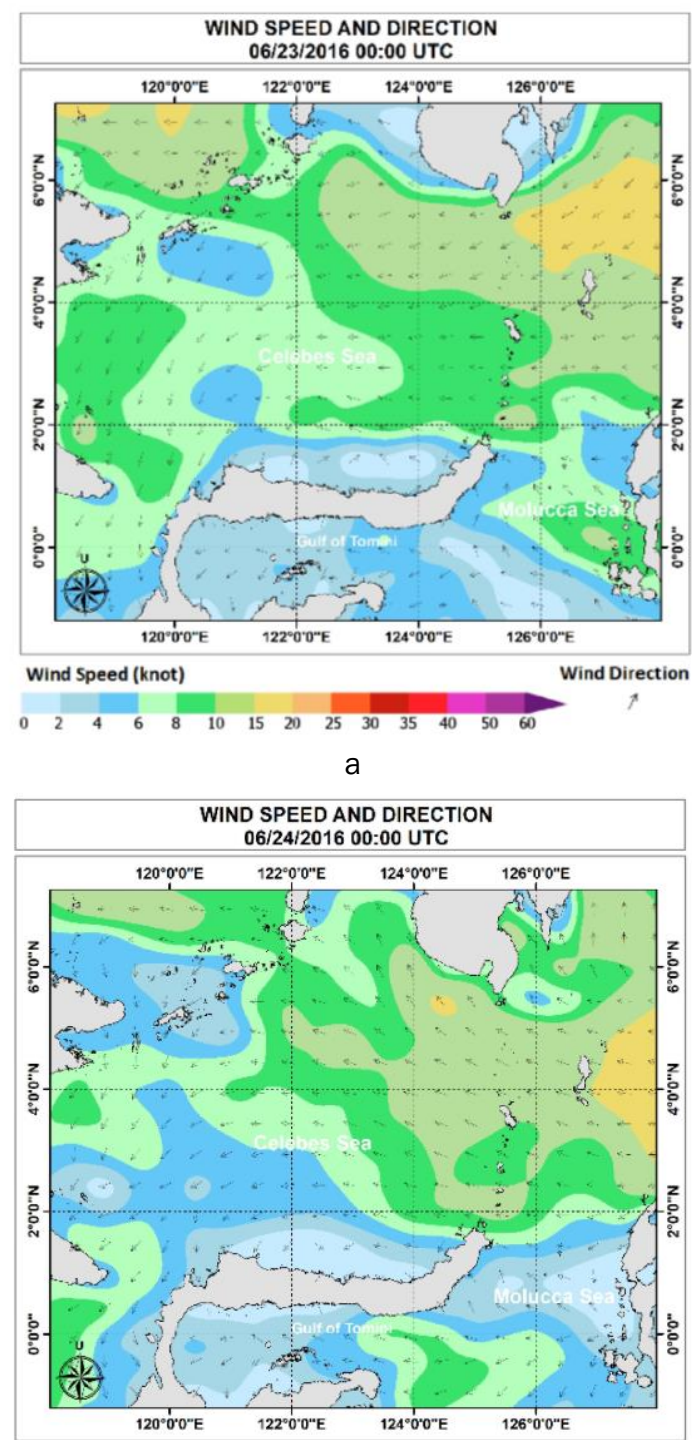

Wind Speed (knot) Wind Direction

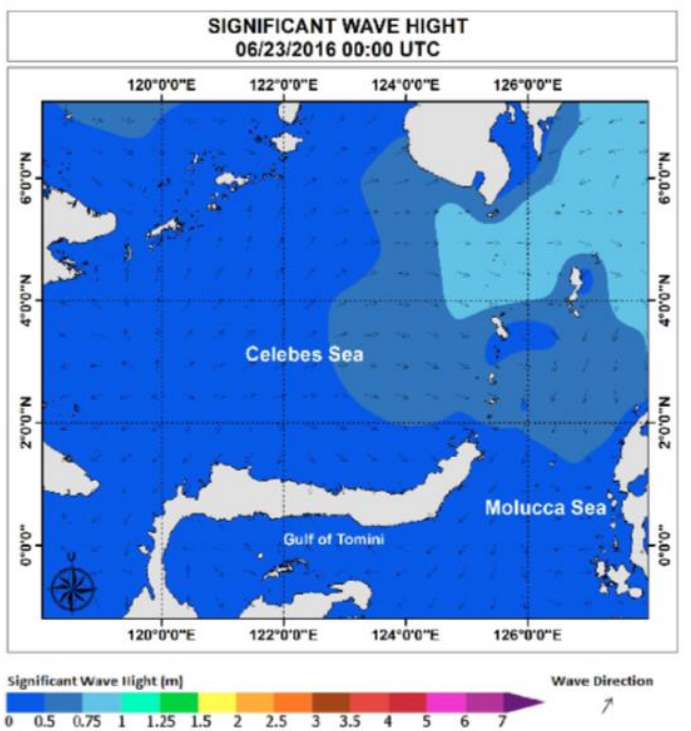

$\mathrm{b}$
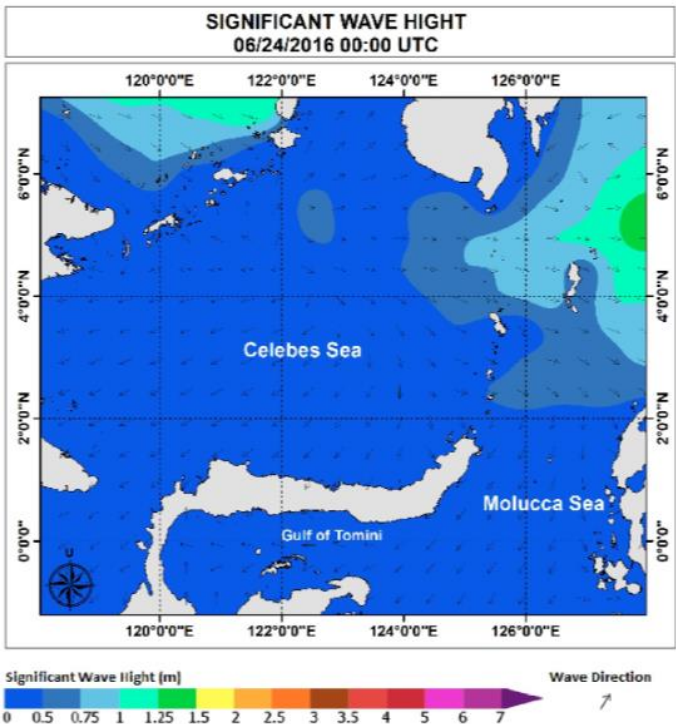

C

Figure 5. Analysis map of wind and significant wave in the final phase (23 - 24 June 2016)

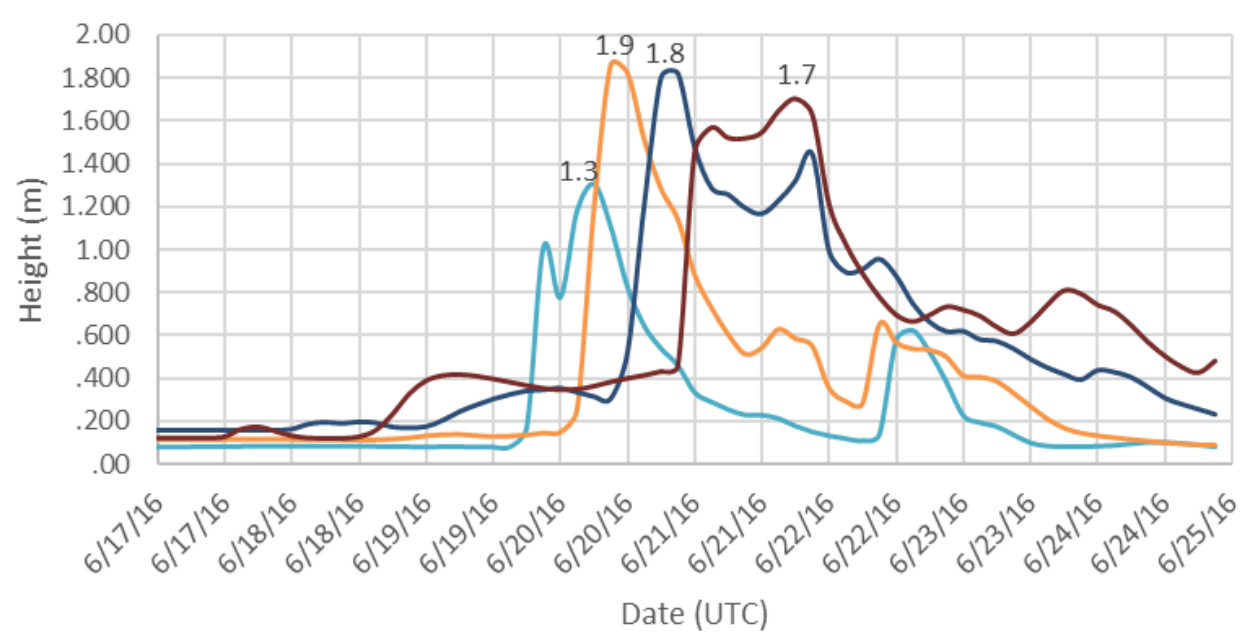

Figure 6. Graphs of Significant wave height on line 1

Note : _ A1=220E,4N; - B1=22E,4N; — C1=224E,4N; D D1=226E,4N 


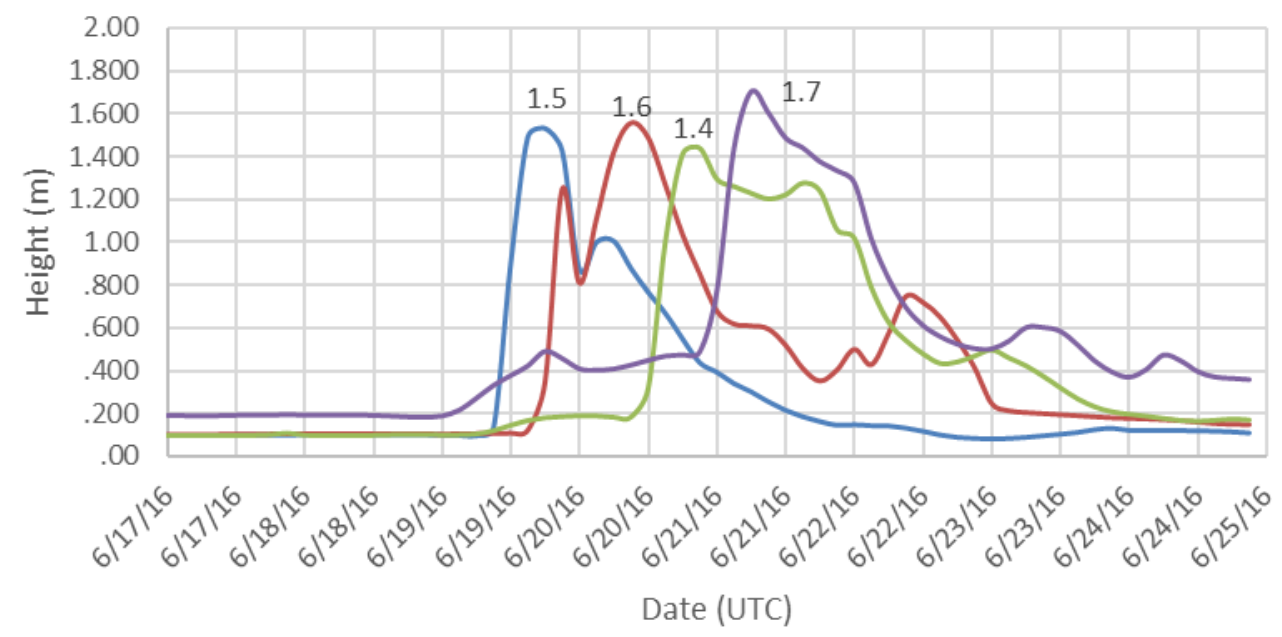

Figure 7. Graphs of Significant wave height on line 2 Note : _ A $1=220 \mathrm{E}, 4 \mathrm{~N} ;$ - B1=22E,4N; —C1=224E,4N; — D1=226E,4N

Significant wave conditions on line 1 (A1, B1, C1, D1).

Figure 6 is a high-wave graph line 1 at four sample points at $4{ }^{\circ} \mathrm{N}$ latitude. In the initial phase the significant wave height at all four points on line 1 is in the range 0.1-1.0 $\mathrm{m}$. The highest of significant wave heights in sequence at point $\mathrm{A} 1 ; \mathrm{B} 1 ; \mathrm{C} 1$ and $\mathrm{D} 1$ are 1.0; $0.1 ; 0.3$ and $0.4 \mathrm{~m}$. Significant wave height at peak phase is in the range 0.1-1.9 $\mathrm{m}$. At this phase the highest significant wave height is sequentially at point A1; B1; C1 and D1 are 1.3; 1.9; 1.8 and $1.7 \mathrm{~m}$. Then the wave height decreases in the final phase (23 - 24 June 2016) that is in the range 0.1-0.8 m, the highest significant wave height sequence at point $\mathrm{A} 1$; B1; C1 and D1 are 0.2; 0.4; 0.6 and $0.8 \mathrm{~m}$.

Waves at point $\mathrm{A} 1$ rise first compared to other points (B1, $C 1$ and $D 1$ ). This shows that the high wave area moves from west to east i.e. from point $A 1$ to $\mathrm{B} 1$ to $\mathrm{C} 1$ then to $\mathrm{D} 1$. This condition can also be seen in Figure 4.

Significant wave conditions on line 2 (A2, B2, C2, D2)

The wave conditions in line 2 are not much different from the wave conditions in line 1 . The graph in Figure 7 shows that the high wave area also moves from west to east ie from point A2 to B2 to C2 then to D2.

Significant wave heights at all four points are in the range of $0.1-1.5 \mathrm{~m}$ in the initial phase. In sequence of the highest significant wave height at point A1; B1; C1 and D1 are 1.5; 1,2; 0.2 and $0.5 \mathrm{~m}$. Significant wave height increased in peak phase that is in the range 0.1-1.7 $\mathrm{m}$. High The highest significant wave in this phase sequentially at point A1; B1; C1 and D1 are $0.9 ; 1.6 ; 1.4$ and $1.7 \mathrm{~m}$. The wave height decreases in the final phase ie in the range $0.1-0.8$ $\mathrm{m}$, and the highest significant wave heights successive at point $\mathrm{A} 1 ; \mathrm{B} 1 ; \mathrm{C} 1$ and $\mathrm{D} 1$ are $0.1 ; 0.2$; 0.5 and $0.6 \mathrm{~m}$.

\section{Conclusion}

The low-pressure circulation system near the Sangihe-Talaud Archipelago triggers the extreme weather resulting in high winds and high waves in the region. The high wave area moves from west to east ie from the western Sulawesi Sea to the Waters of the Sangihe-Talaud Islands. The increase in significant wave height is proportional to the increase in wind speed. Wavewatch III model output data can be used for high-wave analysis.

\section{References}

As-syakur, A. R., 2007. Identifikasi Hubungan Fluktuasi NIlai SOl terhadap Curah Hujan Bulanan di Kawasan Batukaru-Bedugul, Bali. Jurnal Bumi Lestari, VII(2), pp. 123-129.

BMKG (Badan Meteorologi Klimatologi Geofisika), 2017. Pusat Meteorologi Maritim BMKG Ocean Forecast System (OFS). [Online] http://peta-maritim.bmkg.go.id/static/

BMKG (Badan Meteorologi Klimatologi Geofisika), 2016. Marine Integrated Data and Analysis System. [Online] http://202.90.199.148/

BBC Indonesia, 2016. Transportasi lumpuh, bantuan ke pulau-pulau di Sulawesi Utara terhambat. [Online] http://www.bbc.com/indonesia/ 
berita_indonesia/2016/06/160622_indone sia_bencana_sitaro_sangihe\#orb-banner

Bureau of Meteorology, 2016. MSLP Analysis (Manual) SE Asia / Western Pacific. [Online] http://www.bom.gov.au/australia/charts/arc hive/index.shtml

Eshleman, J.L., Barnard, P.L., Erikson, L.H. \& Hanes, D.M., 2007. Coupling alongshore Variations in Wave Energy to Beach Morphologic Change using the SWAN Wave Model at Ocean Beach, San Francisco, CA. Oahu, 10th International Workshop on Wave Hindcasting and Forecasting (Oahu, Hawaii), Paper F.

Hidayat, M.A. \& Hari, A., 2016. Gelombang Laut di Sulawesi Utara Capai 6 Meter. [Online] http://www.viva.co.id/berita/nasional/7879 88-gelombang-laut-di-sulawesi-utara-capai-6meter

Karsidi, A., 2014. Bersama Menata Indonesia Yang Lebih Baik, Jakarta: Badan Informasi Geospasial.

Kaunang, Bernadus, I.R. \& Alfian, T.I., 1999. Bulan Sabit di Nusa Utara Islam di Kepulauan Sangihe dan Talaud pada abad ke-16 dan 17. Jogjakarta: Universitas Gajah Mada.

Oktaviani, C., 2014. Prediksi Curah Hujan Bulanan menggunakan Jaringan Syaraf Tiruan dengan Beberapa Fungsi Pelatihan Backpropagation (Studi Kasus: Stasiun Meteorologi Tabing Padang, Tahun 2001-2012). J. Fisika Unand, 2(4): 228-237.

Ortiz-Royero, J.C. \& Mercado-Irizarry, A., 2008. An Intercomparison of SWAN and WAVEWATCH III Models with Data from NDBC-NOAA Buoys at Oceanic Scales. Coas. Eng. J. 50(01):4773. doi: 10.1142/S0578563408001739
Ramdhani, A., 2015. Pengaruh Siklon Tropis dan Madden-Julian Ocillation (MJO) terhadap Kejadian Gelombang Tinggi di Perairan Indonesia bagian Dalam, Bandung: Institut Teknologi Bandung.

Rildo, M., Prabowo, B.B. \& Wicaksono, A., 2016. Evaluasi Kinerja Angkutan Kapal Laut Tujuan Surabaya-Makassar. J. Mahasiswa Jurusan Teknik Sipil, 1(1): 213-223.

Rustendi, S.H., 2015. Pelaksanaan Ganti Rugi Terhadap Kerusakan Barang melalui Laut pada PT. Asuransi Rama Satria Wibawa Surakarta. Karya IImiah Mahasiswa Fak. Hukum, 1(2): 1-12.

Sofian, I., 2012. Simulasi Storm-Surge di Selat Bangka dengan menggunakan Coupled Adcirc dan SWAN Model. Majalah IImiah Globe, 14(2): 99-109.

Srisurya, 2016. Ini Lokasi Dan Daftar Korban Bencana Alam Di Sangihe Talaud. [Online] Available at: https://beritamanado.com/inilokasi-dan-daftar-korban-bencana-alam-disangihe-talaud/

Suwardjo, D., Haluan, J., Jaya, I. \& Poernomo, S.H., 2010. Keselamatan Kapal Penangkap Ikan, Tinjauan dari Aspek Regulasi Nasional dan Internasional. J. Teknol. Perikan. Kel., 1(1): 113.

Tolman, H.L., 2014. User manual and system documentation of WAVEWATCH III version 4.18. College Park: National Centers for Environmental Prediction NOAA.

Zijlema, M., 2010. Computation of Wind-Wave Spectra in Coastal Waters with SWAN on Unstructured Grids. Coast. Eng. J., 57(3): 267-277. doi: 10.1016/j.coastaleng.2009. 10.011 